\title{
Sierra Leone:
}

\section{Mapping the Disarmament, Demobilisation- Remobilisation and Reintegration of Ex-Combatants. Prospects for Sustainable Peace}

\author{
James OKOLIE-OSEMENE
}

\begin{abstract}
Disarmament, demobilisation and reintegration (DDR) programmes are necessary in states that experience armed conflict. Several post-conflict societies are usually characterised by the activities of individuals who undermine state building efforts and prefer to work against joint problem solving aimed at sustaining peace. The study explores the change and continuity in the DDR programme and prospects for sustainable peace in Sierra Leone. With primary and secondary sources, including key informant interview with a former Minister, the paper responds to these questions: To what extent did remobilisation undermine peace agreements? How were the weapons and ex-combatants controlled by the government? What were the lessons and challenges of the DDR programme? How are the stakeholders sustaining post-DDR peace at the community level? The success of the state building was occasioned by the joint problem solving approach adopted by the National Committee for Disarmament, Demobilisation and Reintegration (NCDDR), ECOMOG troops, the UN Observer Mission in Sierra Leon, and other stakeholders at the community level. This paper stresses that the remobilisation of ex-combatants increased the intensity of the war which necessitated more external intervention to create enabling environment for state building and security sector reforms. Sustaining peace in Sierra Leone demands continuous empowerment of youths and their
\end{abstract} active involvement in informal peace education. Post-DDR peacebuilding should be more youthfocused and development oriented to prevent the resurgence of armed conflicts.

Keywords: DDR, Ex-combatants, Peace agreement, Remobilisation, State building.

James OKOLIE-OSEMENE

Department of International Relations,

Wellspring University, Nigeria

E-mail: okolieosemenej@gmail.com

Conflict Studies Quarterly

Issue 34, January 2021, pp. 20-44

DOI: $10.24193 / c s q .34 .2$

Published First Online: 05 January /2021 


\section{Introduction}

"Peace cannot be kept by force. It can only be achieved by understanding." Albert Einstein

Sustaining peace in post-conflict societies is usually an arduous task considering the involvement of different stakeholders, the multiplicity of actors and how the contestations between them create discord and sometimes escalate tension that would have been contained if they embraced peace processes. State building complexities are usually occasioned by the inability of stakeholders to reach agreement on several state matters and this has remained one of the causes of armed conflict in many parts of the world. Just like some scholars have concluded that conflict is an aspect of human society, armed conflict is one of the features of modern state system to the extent that belligerent parties usually engage in warfare for many months or years.

Historically, Sierra Leone was a peaceful society, a country that had peacetime after independence and later began to record decades of instabilities with attendant insecurities (human and national security complexities) to the extent that these affected sustainable livelihoods and the political life of the country. This had implications for regional stability in West Africa as people became displaced by the crisis that greeted the war.

Since 1992, intra-state armed conflicts that displaced millions led to most disarmament, demobilisation and reintegration (DDR) interventions were concentrated in Africa,

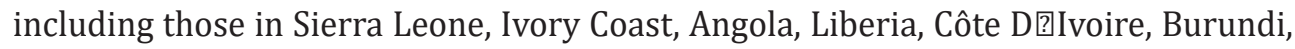
Sudan, the Democratic Republic of Congo and Niger Delta in Nigeria (Abatneh, 2006, Hanson, 2007; Edmonds, Mills \& Mcnamee, 2009; Joshi \& Quinn, 2012). The major advantage of the DDR programmes is that hundreds of thousands of combatants were disarmed and peacebudling initiated. One significant thing about most of the conflicts is that they were either political violence or social conflict, having majority of youths as combatants.

Armed conflict in Sierra Leone and urgent need for stability necessitated the agreement achieved through facilitated bargaining that paved way for disarmament, demobilisation and reintegration (DDR) programme which started in May 2001, implemented by the Government of Sierra Leone with the support of the World Bank, and other international institutions and non-governmental organisations (NGOs). Sierra Leone's model of DDR is one of more than 60 DDR operations that were implemented since the 1990s, most of them in the past three decades, and this is why DDR is described as a 'growth industry' (Muggah, 2010). The 1991-2002 intractable conflict in Sierra Leone adversely affected the operations of the criminal justice institutions, especially the police, prisons and judiciary with belligerent parties preventing the smooth operation of the institutions, destroying the country's infrastructure and killing their personnel (Raleigh \& Dowd, 2012). Consequently, state-building initiatives were undermined throughout the pe- 
riod of instability. The conclusion of the DDR of combatants from all warring parties in January 2002 officially marked the end of the civil war that threatened stability of Sierra Leone, though all the programmes associated with DDR ended officially in 2004. The war in Sierra Leone was one of the 232 documented active armed conflicts since the end of World War II (Varisco, 2009).

Disarmament, demobilisation and reintegration (DDR) programmes have become a regular component of post-conflict reconstruction and state building efforts across the world. However, the reinsertion or reintegration of ex-combatants/ex-militias into civilian life is often problematic, controversial and threatened by the activities of spoilers. This becomes a problem considering the significance of the reintegration phase to the success of the whole DDR programme. These with some institutional lapses further pose serious threats to the long term sustainability of peace and security. Sierra Leoneans found themselves in a situation which Nwoko (2011) sees as failure of dialogue in the management of intra-state conflicts that heightened arms proliferation and the militarism approach to conflict management. This motivated the proliferation of arms with implications for human security. Instead of peaceful management of the conflict, actors adopted confrontational conflict handling style and this made militarism to escalate the conflict.

According to Ploughshares (2002) the civil war in Sierra Leone, where small arms and light weapons (SALW) were the main engine of violence, saw some 50,000 people killed, 30,000 had their limbs amputated, and 215,000-257,000 women were victims of sexual violence (Keili, 2008). So DDR was a roadmap to peacebuilding while peacebuilding was a platform for sustainable peace and security.

The need to revisit the DDR experience in Sierra Leone necessitated this paper considering that several studies have examined the armed conflict in the country with little consideration for the change and continuity in the DDR programme which disarmed combatants, and prospects for sustainable peace in Sierra Leone with emphasis on the historical factors that shaped the development of the conflicts in the country in order to offer more insight into the nature and functionality of post-DDR conflict transformation. It offers account of the DDR from the historical contexts to the peace initiatives.

The study responds to these questions: (a) to what extent did remobilisation undermine peace agreements? (b) how were the weapons and ex-combatants controlled by the government? (c) what were the lessons and challenges of the DDR programme? (d) how are the stakeholders sustaining post-DDR peace at the community level?

\section{Method of data collection and analysis}

This qualitative study combined both primary and secondary sources. It involved comprehensive library research and a review of secondary data on the DDR programme in Sierra Leone. The study also involved key informant interview with the former Sierra 
Leonean Information and Broadcasting Minister, Professor Cecil Blake who was part of the DDR programme in the country. The author also explored the websites of the United Nations Office for Disarmament Affairs for data on the role they played in Sierra Leone, and the Peace Accords Matrix database which maps cases of DDR as provided by Kroc Institute for International Peace Studies, University of Notre Dame. The study adopted content analysis in historical context of Disarmament, Demobilisation and Reintegration modelling in Sierra Leone with emphasis on the principles of conflict transformation.

\section{Conceptual Clarifications}

\section{(a)Disarmament, Demobilisation and Reintegration}

Disarmament, Demobilisation and Reintegration (DDR) refers to a process that contributes to security and stability in a post-conflict recovery context by removing weapons from the hands of combatants, taking the combatants out of military structures and helping them to integrate socially and economically into civil society.

Apart from the internal disarmament that focuses on the removal of arms from individuals, another aspect is nuclear disarmament which focuses on state actors on their need to become signatories to treaties that limit proliferation. An example is the 2017 Treaty on the Prohibition of Nuclear Weapons (TPNW) promoted by a transnational network of government agencies, international organisations, and civil society actors with the aim of preventing the humanitarian, environmental, and developmental impacts of nuclear detonations (Egeland, 2019). DDR encompasses three broad functions: Disarmament: the collection and disposal of weapons used by combatants; Demobilisation: disbanding military structures transform from wartime to peacetime environment, Reintegration; facilitating long-term peace and the return of former combatants to civilian life. This programme is designed for ex-combatants or ex-armed militia that accept peaceful means of settling dispute or whatever agitation that led to armed struggle, through amnesty deal or peace agreement.

\section{(b) Ex-Combatants}

Ex-Combatants refer to a group of people who actively participated in violent conflicts either in form of rebellion, insurgency, struggle for power or control of resources against a state. The conflicts in this context often involve the proliferation of small arms and light weapons. Their willingness to renounce violence and embrace peace makes them ex-combatants. The involvement of women and children in terms of provision of logistics in the conflict increased the number of ex-combatants in Sierra Leone.

\section{DDR as a global framework for achieving peace and security}

The fact that armed conflicts decline or end does not stop combatants from handling the weapons at their disposal. Where there is weakness of social control or implementation of the rule of law, most people would stockpile arms for illegal use. It has been 
established that, partly because of the continued presence of automatic rifles, grenades, and handguns, arming in self-defence becomes normalised (Muggah, 2005).

Therefore, suspension of hostilities as well as successful disarmament, demobilisation and reintegration (DDR) start with the ability of warring parties or parties involved in armed conflict to realise the fact that violence is no means to achieving their goals. Knight (2010) contends that whenever a conflict comes to an end, either through a peace agreement or as a result of military victory, the war-torn country needs to address the issue of surplus troops who may be discharged from military and rebel forces, which for security purposes, are being disbanded. Even United States Institute of Peace (USIP) supports the universal view that disarming and demobilising ex-combatants is a highly visible process that can increase public confidence in the peace process.

As peacebuilding initiative, DDR is required to discourage armed groups from adopting violence as a way of addressing their concerns. Disarmament is the first step of a DDR process which is concerned with the removal of weapons, ammunitions and explosives, and signifies an end to people's active involvement in any combat (United Nations, 2000). As essential part of DDR, disarmament provides a secure environment in which demobilisation and reintegration can take place as part of a long term peacebuilding strategy. The belief that the availability of weapons armed conflict in many parts of the world makes disarmament relevant. UNDDR Resource Centre outlines the four main phases of disarmament component of DDR programme: (1) information collection and operational planning; (2) weapons collection or retrieval operations; (3) stockpile management; and (4) destruction. It is also shaped by four guiding principles namely: national sovereignty, armed violence reduction, safety and capacity development. In essence, what disarmament phase of DDR entails is that weapons belonging both to combatants and the civilian population are collected, documented, and disposed of (in most cases, destroyed) (Hanson, 2007). This paves way for demobilisation.

Demobilisation according to Muggah, Maughan and Bugnion, (2003) is the formal and usually controlled identification, registration and discharge of active combatants from regular or irregular forces. Through demobilisation, repentant combatants are induced to disband their military organization and structure and shift from 'combatant' to 'civilian' status (Ball \& de Goor, 2006). Disbanding them becomes pertinent to prevent remobilisation.

Prioritising pre-disarmament planning prevents DDR from failing from the onset considering how it offers opportunity to determine who is to be disarmed, establish collection sites, timetable, disposal of collected weapons and post demobilisation needs of the ex-combatants (Laurence \& Shie, 2003). In their peacebuilding works at the North Rift, Nolasco Lazarus and Munene Martin (2012) discovered that successful cooperation and coordination among all actors guarantees successful disarmament, demobilisation and reintegration, of course with proper planning. The pre-DDR planning, cooperation and 
coordination of stakeholders makes it easier for them to check remobilization possibility, thereby permanently addressing the security challenges confronting a nation due to availability of arms in the wrong hands.

In most DDR programmes, rehabilitation phase comes before proper reintegration into the larger society to enable ex-militias to get used to civilian ways of life. Mental demobilisation is an aspect of DDR that needs proper consideration by stakeholders to ensure that achievements recorded through DDR programmes are sustained without being undermined by return to armed conflict. This is not disputable because the minds of ex-combatants would determine their actions. According to Cuny (1991) inability of governments to demobilise youths mentally is one of the precipitants of soaring crime rates and enduring political instability in former conflict theatres (as cited in Faleti, 2005, p. 382). This explains why there is a problem of remobilisation thereby justifying the return to violence. Proper consideration of psychological needs of ex-combatants remains crucial for stability in post conflict societies considering the implication of inadequate confidence building initiatives during DDR programme.

\section{Oligopolies of violence theory and the principle of conflict transformation in the context of the war in Sierra Leone}

Oligopolies theory was developed by Mehler to explain the post-conflict situation where the state is unable to fulfill its mandate to exercise a legitimate monopoly of physical coercion usually due to the activities of non-state actors (Lamback, 2007). This means that there is an unfulfilled demand for protection in such an environment especially when armed groups remobilise or reject the peace initiatives by state actors. As a result, alternative producers of violence get involved in security market, thereby making social change a necessity through the timely implementation activities that would restore order and sustain peace (Lederach, 1998). The thrust of this theory is that post-conflict societies also share similarities in the area of peacebuilding by facilitating reconstruction and confidence building. The theory classifies armed conflicts into high and low intensity conflicts. For instance, Lamback (2007) argues that Sierra Leone showed the fractal nature of security markets: at local and individual level, new actors emerge while others fade away. While high intensity conflicts closely resembled classical models of civil war, often resolved through peace agreements or military victories, low intensity conflicts are associated with banditry, riots and criminal violence. The involvement of multilateral forces shows external military intervention. The armed conflict in Sierra Leone was classified as a high intensity conflict which involved external intervention such as United Nations and ECOWAS.

In high intensity conflicts, military intervention could lead to the entry of a strong competitor into the security market, usually resulting in a rapid change of market structure. The outcome of peace initiative is that a peace agreement supports the eventual emer- 
gence of a monopoly of violence either through the demobilisation of ex-combatants or their integration into a national army. A peace agreement is also supposed to reduce hostility perceptions among groups, making interaction between market actors less conflict oriented, such as power-sharing agreements (Lamback, 2007).

Similarly, conflict transformation demands for change of situations. From the process of conflict transformation, it is not disputable that DDR aims at achieving positive peace. Several theorists have described conflict transformation as a continuous process which endeavours to focus on the root of every conflict (Galtung, 1996; Väyrynen, 1999; Lederach, 1998) with the aim of creating "new social relations, institutions, and visions" in the society (Väyrynen 1999, p. 151, as cited in Botes, 2003). Conflict transformation processes are observed in the area of nation building, national reconciliation and healing (Botes, 2003). All these enhance state building. From the implementation of DDR programme in Sierra Leone, it is obvious that the aim was to create peaceful society.

Significantly, Schirch (1999, as cited in Botes, 2003) outlines the four dimensions that should be taken into consideration in order to transform systems include: (a) personal, or individual changes in the emotional, perceptual, and spiritual aspects of conflict; (b) relational, or changes in communication, interaction, and interdependence of parties in conflict; (c) structural, or changes in the underlying structural patterns and decision making in conflict; and (d) cultural, or group/societal changes in the cultural patterns in understanding and responding to conflict. Achieving peace means that actors involved need to focus on issues based on context with the aim of achieving desired change through understanding.

\section{Historicising the contexts of Disarmament, Demobilisation and Reintegration Programme in Sierra Leone}

The proliferation of small arms and light weapons (SALW) crimes in many African states which have been affected by social conflicts, and this creates the climate of insecurity (Edeko, 2011). SALW are convenient and attractive to rebel groups in many parts of Africa due to their availability, affordability, destructiveness, easy to transport and smuggle, and use in attacks unlike heavy conventional arms, such as artillery pieces and tanks that are more expensive and procured by security forces (Boutwell and Klare, 2000).

Sierra Leone, a country that recorded political instabilities, coups and counter coups that made governance brutish. Rebellion and insurgency characterised the armed conflict in Sierra Leone. According to reports, Taylor kept up his support for the Revolutionary United Front (RUF) rebels in neighboring Sierra Leone and also provided support to some rebels in neighboring Guinea (Obi, 2009). Apart from smuggling of diamonds that attracted several actors, the lucrative nature of the business of diamonds was a driver of struggle by actors as Sierra Leone produced $\$ 300$ to $\$ 450$ million worth of diamonds per year in the mid 1990s (Montague, 2002). Post-colonial economic marginalisation, 
exploitation of the labour force, perceived politics of exclusion, motivated the armed conflict, especially as the youthful population could not actualise their human potentials with autocratic gerontocracy in communities (Boersch-Supan, 2012; Tom, 2014).

Violent conflict between elected governments, the mutinous military and the Revolutionary United Front (RUF's) rebellion characterised the country between 1991 and 2002. An estimated 50,000 people were killed and thousands more injured or maimed. Over two million people were displaced with 500,000 fleeing to neighboring countries. Most of the country's infrastructure were destroyed namely roads, hospitals, schools, and commercial enterprises, to the extent that it affected livelihoods, with declined economy and societal relations undermined (Ginifer \& Solomon, 2008). The conflict occurred as a result of both internal and international dynamics. Internally, it was rooted in governance inconsistencies, widespread corruption, and the marginalisation and disempowerment of the rural communities, through monolithic and inefficient central government control over economic and political activities. According to Ginifer and Solomon (2008) various factors were responsible for the crises that exacerbated instability in sierra Leone including mounting foreign debts, worsening terms of trade for the country's limited export commodities, and misguided economic policies. Some macroeconomic and structural reforms initiated by the World Bank/ International Monetary Fund (IMF), and the attendant stringent conditionalities, exacerbated economic instabilities instead of stabilising the economy and restoring growth. The consequence was political instability.

The country became an enclave of instability when the government of then President, Joseph Momoh was attacked by RUF in 1991, after the rebel group got external support from National Patriotic Front of Liberia (INPFL) (Obi, 2009), and this marked a watershed in the socio-political history of Sierra Leone as life became brutish with the violation of human rights as a result of the events that followed the incidents. The civil war was characterised by atrocities committed by all factions including the burning of villages, forced conscription of child soldiers, murder, torture, rape, and mutilation of civilians that affected thousands of people (Richards, 1996; cited in Asiedu \& Berghs, 2012).

Through its anthem, RUF sought to promote the group's message titled "Footpaths to Democracy,", thus:

Where are our diamonds, Mr. President?

Where is our gold?

RUF is hungry to know where they are,

RUF is fighting to save Sierra Leone,

Our people are suffering without means of survival,

All our minerals have gone to foreign lands.

RUF is hungry to know where they are,

RUF is fighting to save Sierra Leone (Montague, 2002). 
With the backing of the Armed Forces Revolutionary Council (AFRC) RUF was able to overthrow the government of President Kabbah on 25 May 1997; and in February 1998, the Nigerian led peace-keeping force, the Economic Community of West African States Monitoring Group (ECOMOG) forced the rebel movement out of power and reinstated President Kabbah. During the year 1998, lethality of the violence escalated due to RUF's atrocities that undermined human and national security.

The factors that triggered the war in Sierra Leone have also been highlighted by Dupuy and Binningsbø:

The war was rooted not in ethnic or religious rivalries, but rather in the gradual withdrawal of the state from rural areas and the subsequent collapse of the country's patrimonial system of governance. The RUF's stated aims of overthrowing the government spoke to the long-running grievances of rural people against an overly centralised, corrupt government that had long neglected socio-economic development outside the capital and that had left many feeling disenfranchised and excluded. In particular, the role of the country's massive diamond deposits in exploitative agrarian relationships that marginalised young people helped to mobilise support for the RUF (2008, p. 1).

The war in Sierra Leone began when a small group of rebels called the Revolutionary United Front (RUF) forced their way into the country from neighboring Liberia, backed by Charles Taylor, and their activities made peace elusive to the people as Sierra Leone recorded debilitating lethal violence that killed tens of thousands of civilians, displacing hundreds of thousands thereby making them homeless (Humphreys \& Weistein, 2005, p. 8). As usual with leaders of rebellious groups, they justified their campaign to have a human face by asserting that the RUF engaged in armed struggle with the aim of salvaging the country from the claws of the oppressive regime of the All People Congress (APC) which ruled from 1968 to 1992 (Gbla, 2003, p. 171). The complexities associated with the war manifested as it was problematic identifying the areas of involvement by different stakeholders and shadow parties.

It became a regional war with global connections: Nigerian-led ECOMOG (Economic Community of West African States' Monitoring Group), got additional mandate to restore peace in Sierra Leone after involvement in Liberia since formation in 1990, cooperated with the government, and supported by the British government and the United States. The war created multiple security provision initiative as private military companies, such as the Gurkha Security Guards (GSG) Ltd and the Executive Outcomes (E0) and Sandline International got contracted by the government to provide security and train the Kamajor militia. The Armed Forces Revolutionary Council (AFRC), renegade members of the Republic of Sierra Leone Military Forces (RSLMF), entered into an "alliance of convenience" with the RUF, the primary rebel group in the Sierra Leone conflict 
(Ginifer \& Solomon, 2008). This was complicated by shadow party states like Libya, Liberia, Burkina Faso, Côte d'Ivoire.

By January 1995, RUF was able to occupy some diamond mines in Sierra Rutile and Sieromco thereby making it difficult for the government to have the capacity to repay IMF loan as expected (Montague, 2002). Successful targeting and occupation of mining communities demonstrated that RUF was determined to change the rhythm of the war against the government.

Through an election, Ahmed Tejan Kabbah was elected president in 1996, and later toppled in May 1997 by the AFRC military junta, led by Corporal Johnny Paul Koroma. Efforts to reduce numbers in the army and the loss of privileges of junior officers who felt economically and politically marginalised, as well as hostility to the increasing influence of the Kamajor militia, contributed to the coup (Kandeh, 2004). The junta was ousted by ECOMOG forces and in 1998 Kabbah returned from exile as President; by January 1999 RUF rebels invaded Freetown on a killing spree but were pushed back by ECOMOG troops whose presence/response portrayed negative peace (Ginifer \& Solomon, 2008).

Unfortunately, the inability of successive leaders to offer the society much desired good governance coupled with their politics of exclusion and selfish desire to remain in power created development gap that increased opportunity for youths who dominated the rebellion in demonstrating their position as vandals, to embrace violence as option to end perceived exploitation and marginality (UNAMSIL, 2003; Boersch-Supan, 2012; Tom, 2014). Moreover, the emergence of Kamajor militia group was the outcome of the 'sobelisation' of the national army, as the civil defence force made up of local hunters and other volunteers armed with locally made guns and weapons (Ukeje, 2003). With this, they became a force to reckon with in communities that had poor footprints of security forces thereby responding to the traditional security provision need, defending the people from rebels. The escalation of the civil war made the government to engage the Kamajor to contain RUF guerrillas whose campaigns threatened Freetown and environs. Their defensive warlike strategy positioned them to fend ambushes and raids by RUF fighters, thereby neutralising their sabotage operations. The consequence of sobelisation was that armed forces became compromised making it difficult to differentiate their modus operandi from the rebels at a time when national security was at stake and this positioned the civil defence militia as a stabilising force. The government of Sierra Leone was in a state of confusion with such a difficult situation.

With sobelisation, there was a tripartite war as shown by the diagram here

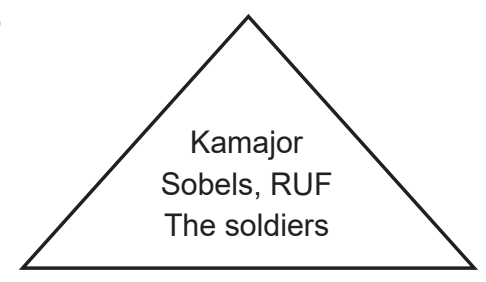




\section{The Peace Initiatives for DDR Planning and Implementation in Sierra Leone}

This section explores the nature of DDR especially those significant efforts that were made by the authorities in Sierra Leone in planning their DDR programme modeled within the framework of peace agreement. According to UNAMSIL (2003, p. 4), given the dynamics of disarmament, remobilisation and reintegration, it is important to note that:

There is no generic template of DDR practice that can be superimposed on post-conflict scenarios throughout the world. DDR processes must be carefully and sensitively custom designed for each scenario, by teams with intimate knowledge of the respective theatre, the players, the overall objective of the peace process and the tools available.

Notably, peacebuilding programmes were based on liberal peace model which prioritises economic and political liberalisation in post-conflict environments to sustain the peace (Tom, 2014).

The DDR programme was premised on the fact that it is difficult to plan any programme aimed at removing arms from the wrong hands without creating environment embedded in conflict transformation and principles of conflict transformation with the core objective of ensuring that the post-conflict society is not thrown into another chaotic environment again. Observations have shown that the way DDR programme is planned by stakeholders will determine its success. The planning of DDR was done in a manner that would restore the much needed peace.

Most times, roadmap to successful DDR programmes starts with peace agreements or any form of peace accord. Without a negotiated agreement, it is difficult to commence any DDR programme and this could make activities of spoilers to be on the increase. The opportunities offered by peace agreements in DDR programmes are aimed at achieving sustainable peace. Peace agreements are not only designed to terminate civil wars but also to give room for reconciliation, reconstruction and development. The successful implementation of every DDR programme greatly depends on the nature of agreement, acceptance and behaviour of parties to the agreement.

Table 1. Conflict handling mode

\begin{tabular}{lll}
\hline & \multicolumn{1}{c}{ Accommodation } & \multicolumn{1}{c}{ Compromise } \\
\hline Outcome & Little fuss -- no feathers ruffled & No one returns empty-handed \\
Gain & Others may view you as supportive & Keeps the peace \\
\hline
\end{tabular}

Source: Glen (1981), Glen, Whitmeyer, \& Stevenson, K. A. (1977); Kozan (1997; 2002).

As shown by table 1, the DDR programme took cooperative and assertiveness dimensions at different stages, from the period of demand/negotiation stage to the agree- 
ment in Sierra Leone through accommodation and compromise. There was no better option than accommodation considering the needed change of perceptions as part of confidence building.

The government established the National Committee for Disarmament, Demobilisation and Reintegration (NCDDR), chaired by the president, in July 1998. An Executive Secretariat reporting to the NCDDR was set up, with responsibility for the overall planning and implementation of the Disarmament, Demobilisation and Reintegration (DDR) programme. The government's policy and programme framework were developed in close consultation with all the relevant stakeholders: the West African peacekeeping force ECOMOG; the UN Observer Mission in Sierra Leone (UNOMSIL); UN agencies, the UK's Department for International Development (DFID); the World Bank; NGOs; the Armed Forces of Sierra Leone (AFSL); and the affected communities. The Abuja Agreement signed in November 2000 initiated the elements of the Lomé Peace Agreement. The UN finally took a leadership role in disarming the factions. Peace agreement laid the foundation for DDR in Sierra Leone.

Political guarantees are "integral aspect of peace agreements and involve political and practical support to assist implementation and assurances that external parties will use their influence to foster parties' compliance with the terms agreed" (Griffiths \& Barnes, 2008, p.12). Francis (2000, p. 364) explains that apart from power sharing, amnesty is a very important aspect of political settlements during armed conflict and military intervention. The devastating war in Sierra Leone required quick intervention which led to peace agreements that paved way for the DDR. Rakate (2008) notes that cease fire agreements propose measures geared to promote peace and reconciliation (like that of Sierra Leone in Lomé on July 7 1999). DDR programme in Sierra Leone emerged from the following peace agreements:

1. Abidjan - November 30, 1996

2. Conakry - October 23,1997

3. Lomé - July 7, 1999.

But the implementation of all the agreements, from the first to the last was challenging. The first peace process between the government and the RUF was initiated in late 1995, which prepared the ground for agreement signed in Abidjan, Côte d'Ivoire, in November 1996. Initiated by the NGO International Alert, the process was taken over by the Organisation for African Unity (OAU) in the summer of 1996.

The agreement contained an amnesty for the RUF, provisions for transforming the RUF into a political party, withdrawal of regional forces within three months, expulsion of the private security firm Executive Outcomes, and provisions for electoral, judicial and police reform as well as for the protection of human rights. The accord did not reach a proper implementation stage, in part because RUF leader Sankoh refused to allow UN 
peacekeepers or monitors to be deployed after the expulsion of Executive Outcomes. Fighting resumed less than two months after the accord was signed (Gberie, 2000). In between the aforementioned agreements was remobilisation occasioned by lack of commitment by the rebel forces.

In preparation for the peace talks in early 1999, a three-day consultative conference hosted the political leadership, traditional leaders and representatives of civil society to debate the terms of a peace agreement. The conference was organised by the National Commission for Democracy and Human Rights, a government body, and followed extensive regional consultations that this Commission had undertaken throughout Sierra Leone over the previous two months. The conclusions of the conference on questions of justice and power-sharing were different from what was ultimately agreed in Lomé. In consensus, the conference concluded that in the interest of peace, national reconciliation and unity there should be an amnesty for all combatants, but cases of serious human rights violations should go through the proposed Truth and Reconciliation Commission (Gberie, 2000). Lomé, Togo, was chosen as the venue for the Sierra Leone peace talks because Togo was chairing the Economic Community of West African States (ECOWAS) at that time.

From a position of strength, the RUF reached a negotiated settlement with the Government of Sierra Leone when signing the Lomé Peace Agreement on 7 July 1999. According to the terms of the Agreement, in exchange for disarming, the RUF was given posts within the government, and guaranteed the right to form a political party to contest elections, and the United Nations (UN) Mission in Sierra Leone was formed (UNAMSIL).

Article 1 of the Lome Peace Agreement provided for the immediate suspension of hostilities with the aim of permanently bringing to an end the armed conflict between the government and RUF. Article II mandated the United Nations Observer Mission in Sierra Leone (UNAMSIL) to chair the Ceasefire Monitoring Committee with RUF, Civil Defence Forces (CDF) and ECOMOG as members saddled with the responsibility of monitoring and reporting incidents of violation. Apart from the peacekeeping provision, the Lome Peace Agreement also had security governance component with emphasis on national security, protection of DDR personnel and protection of UNAMSIL (see Article XIII). Article XXIX also took control of the reparations need as it provided for the internal and external stakeholders to design and implement rehabilitation programme for the victims of the war through a special fund provided for the beneficiaries. This component has conflict transformation and peacebuilding value considering the confidence building significance of the initiative. The fact that rebellious group members of RUF, CDF and SLA were given the opportunity to integrate into the newly reformed armed forces (Article XVII) indicated that the conflict actors were ready for sustainable peace and security thereby making the peace initiative a win-win outcome for all. Article XXI 
also considered the necessity to release all prisoners of war and abductees by all actors unconditionally in accordance with the Statement of June 2, 1999 (Peace Accords Matrix). Such goodwill would guarantee peace and sustain constitutional reform as contained in the agreement.

Unfortunately, the RUF which spearheaded the rebellion violated Lomé agreement on several occasions including launching attacks on civilians and UN peacekeepers. British forces were deployed to Freetown to evacuate UK citizens and secure the airport to allow the arrival of UN reinforcements.

The agreement signed on 7 July 1999, called for the demobilisation of the rebel forces, and the incorporation of some into the army (Hayner, 2007), but there is no indication that individuals' past human rights records should be taken into account. The Accord simply states that "those ex-combatants of the RUF, CDF and SLA who wish to be integrated into the new restructured national armed forces may do so provided they meet established criteria." The RUF demanded for a transitional government, in the form of a government of national unity, and insisted that they be allocated half the ministerial positions, which was contested by the government. The government was initially willing to concede only two ministries to the rebels but after much deliberation, the government did awarded four ministerial posts to the rebels.

Hayner (2007) noted that the 1999 peace agreement between the members of opposition and the Government of Sierra Leone received considerable international attention. It ended a war renowned for its brutality, with a rebel force that did not have clearly stated political goal. The peace accord is often remembered internationally for the blanket, unconditional amnesty granted to all warring parties, which met strong international condemnation. The dynamics of negotiation was brought into play during the agreement that led to the signing of the 7 July 1999 agreement in Lomé, Togo, as various people perceived it differently.

For those who identified the violations of the laws of war as severe wrongdoing requiring no pardon, they viewed such an amnesty as unacceptable for the groups that abused human dignity and needed to be punished for their atrocities; while some regarded it as an ice on the cake in the journey to a peaceful Sierra Leone. This was part of UN disclaimer which rightly pointed out that the amnesty was seen as not being within the bounds of international law and acceptable practice. Being a precondition for peace meant it needed not to be ignored despite the grey areas.

Remarkably, several stakeholders took active part in the Lomé talks including RUF and AFRC had their delegations. Also, the Inter-Religious Council of Sierra Leone played a significant role as a stakeholder in the country desirous of correcting any impression on religion being a contributing factor to the conflict. Other Sierra Leone civil society and private sector representatives were also present as observers, some for few weeks 
and others for almost throughout the period. These observers represented a range of organisations, including the Human Rights Forum, the association of war victims and amputees, the Women's Forum, the Labour Congress, the Chamber of Commerce, the Sierra Leone Indigenous Business Association and the Sierra Leone Association of Journalists. The delegates were grouped into three committees, addressing: military and security issues (Gberie, 2000), all saddled with the responsibility of reaching agreement on the main issues through their contributions. With their input through informal lobbying and consultation on the sidelines of the main meetings, the agreement became people-centred.

The National Commission for Disarmament, Demobilisation and Reintegration (NCDDR) identified groups that were to benefit from the DDR programme which included the former members of the Armed Forces Revolutionary Council (AFRC), Revolutionary United Front (RUF) rebels, pro-government Kamajor militia fighters, loyalist soldiers that served with Sierra Leone's largely defunct army, and others from unspecified categories. The Commission also outlined the eligibility criteria in the country's DDR as follows: (1) members of a recognised fighting force in the civil war; (2) Surrender serviceable weapon, a group weapon or ammunition.

Disarming and reintegrating militias without coercive means but through DDR guarantees sustainable security. This is pertinent due to need for confidence building between security forces and ex-combatants. When the security sector is restructured, people's confidence in security operatives will improve and that way, it would be easier for them to share information. The duration was mapped out in different phases from disarmament, demobilisation to rehabilitation and then reintegration. Sierra Leone ended DDR officially in 2002. Generally, Lomé peace agreement was productive considering the success of the DDR programme so far.

\section{The Management of Ex-Combatants and the Weapons of Warfare}

Various stakeholders were involved in the management of the DDR including internal and external stakeholders. External stakeholders include funders, supporters, beneficiaries, partners; internal stakeholders include staff, board members, trustees, include those involved in monitoring. During the DDR in Sierra Leone, multiple stakeholders were involved. The institutional responsibility had the National Commission for Disarmament, Demobilisation and Reintegration (NCDDR) implemented the programme in Sierra Leone.

Moreover, efforts were made to go beyond NCDDR to initiate other disarmament units such as the Community Arms Collection and Destruction (CACD) and Arms for Development (AFD) programmes, as initiated by United Nations Development Programme in collaboration with UNAMSIL and the government of Sierra Leone. Sierra Leone's DDR, according to Asiedu and Berghs (2012), began in earnest in 2001 with 
the disarmament phase which comprises the collection, registration, disabling and destruction of all weapons and ammunitions.

The DDR was funded by UNO, World Bank among others as the country was recovering from years of civil war that led to over 1,000,000 internally displaced persons and 363,000 refugees scattered within West Africa. Generally, World Bank funds and assists in the operation and evaluation of DDR with the primary tasks of (1) giving policy advice, (2) mobilise and manage funds (3) information dissemination to sensitise stakeholders (4) provide technical assistance and (5) leading donor coordination based on request.

From United Nations 2011 report, this process was carried out in 45 reception centers. UNDPKOs shows that over 72,490 people were disarmed and over 30,000 weapons were collected. In the words of Professor Cecil Blake "accounting for the total number of weapons collected was problematic" (personal communication, April 2012). Majority of the initiatives during the DDR programme in Sierra Leone were implemented by the Government of Sierra Leone and World Bank, and UNAMSIL. According to Cecil Blake,

The Government of Sierra Leone categorised, beneficiaries/participants into combatants and victims and were given some incentives. Information dissemination was carried out by the government on the need to sustain stability in the country. The credibility of the army which was undermined during the war had to be restored" (personal communication, April 2012).

The restoration of this credibility was a necessity considering the threat earlier posed in the 1990s by the sobelisation of the armed forces which required confidence building measures to be addressed. Heavy weapons were buried in cemeteries, and some graves were desecrated during the war and weapons buried there. Weapons recovered included small arms and ammunition such as hand grenades, rocket propelled grenades, and mines. This was noted by Professor Cecil Blake during an interview with him when he averred that the government in Sierra Leone was confronted with the problem of what to do with the heavy weapons.

The disarmament process was conducted at reception centres distributed around the country. It included five phases: the assembly of combatants, collection of personal information, the verification and collection of weapons, the certification of eligibility for benefits, and transportation to a demobilisation centre. Disarmed combatants were prepared to return to civilian life in demobilisation sites where they received basic necessities, reinsertion allowances, counseling, and eventually transportation to a local community where they elected to live permanently. In the community, combatants benefited from training programs (largely vocational skills including auto repair, furniture-making, etc.) designed to ease their reentry into the local economy. Operationally, moving more than 70,000 soldiers through this process is an accomplishment in itself, as enumerators worked through both official (UN and government) contacts and local com- 
munity leaders to develop lists of ex-combatants. Teams identified pools of candidates from more than one source: some from the town or village Chief, some from the village youth coordinator, some from various DDR and NCDDR skills training centres, etc. The teams aimed to identify two to three times the targeted number of potential respondents and then to randomly select respondents using different methods. In most cases, Chiefs and DDR staff asked a number of ex-combatants to meet at a public location and teams selected candidates randomly from that pool (Humphreys \& Weinstein, 2005).

On the other hand, the demolisation phase of DDR in Sierra Leone was held at sixteen centers. Combatants were disbanded during this phase. About 71, 043 ex-militants went through the demobilisation process, including 4,751 women and 6,845 children (Carames, Fisas, \& Luz, 2006; cited in Asiedu \& Berghs, 2012). The nature of the armed conflict in Sierra Leone apparently led to the amputation suffered by majority of civilians especially in crisis ridden areas. The government (authorities) set up amputee camps (Interview with the Minister of Information and Broadcasting during the DDR programme in Sierra Leone, Professor Cecil Blake, June 2012) so as to alleviate the sufferings of the people.

Notably, the rules of engagement were periodised in the DDR programmes for strict compliance with stipulated timeframe. This made it possible for disarmament phase to be set out for ex-combatants. With the DDR, it was easier for stakeholders to recover and remove small arms and light weapons (SALW) from the wrong hands, and this restored law and order. Although there were many accords before Lome, that of Lomé was unique because it paved way for the entire DDR and Truth and Reconciliation Commission.

Table 2. Total disarmed and demobilised in Sierra Leone by district

\begin{tabular}{lrrrr}
\hline \multicolumn{1}{c}{ District } & RUF & CDF & Others & Total \\
\hline Bo & 17 & 3,755 & 0 & 3,772 \\
Bombali & 4,049 & 110 & 20 & 4,179 \\
Bonthe & 0 & 1,246 & 0 & 1,246 \\
Western Area & 155 & 1,972 & 163 & 2,290 \\
Kailahun & 6,115 & 1,694 & 40 & 7,849 \\
Kenema & 1,660 & 3,048 & 30 & 4,738 \\
Kolnadugu & 317 & 1,205 & 30 & 1,552 \\
Kono & 3,730 & 2,255 & 38 & 6,023 \\
Moyamba & 1 & 2,938 & 0 & 2,938 \\
Port Loko/Kambia & 1,680 & 5,595 & 126 & 7,401 \\
Pujehu & 0 & 2,962 & 0 & 2,962 \\
Tonkoli & 1,543 & 1,271 & 16 & 2,830 \\
\hline \multicolumn{1}{c}{ Grand Total } & $\mathbf{1 9 , 2 6 7}$ & $\mathbf{2 8 , 0 5 1}$ & $\mathbf{4 6 3}$ & $\mathbf{4 7 , 7 8 1}$ \\
\hline
\end{tabular}

Source: Thusi and Meek (2003). 
The organisation of the DDR in phases indicated that there were instances when some ex-combatants remobilised due to different factors which included security governance, political issues, collapse of agreements by actors, and their inability to develop mutual trust. For instance, between 1998 and 2000, those that were yet to be totally disarmed were potential conflict entrepreneurs who would stop at nothing to foment trouble.

Table 3. Total Disarmed by group

\begin{tabular}{|c|c|c|c|c|c|}
\hline $\begin{array}{l}\text { Category } \\
\text { disarmed }\end{array}$ & $\begin{array}{c}\text { PHASE I } \\
\text { (Sep.-Dec. 1998) }\end{array}$ & $\begin{array}{l}\text { PHASE II } \\
\text { (Oct. 1999- } \\
\text { April 2000) }\end{array}$ & $\begin{array}{l}\text { Interim Phase } \\
\text { (May 2000- } \\
17 \text { May 2001) }\end{array}$ & $\begin{array}{c}\text { PHASE III } \\
\text { (18 May 2001- } \\
\text { Jan. 2002) }\end{array}$ & Total \\
\hline RUF & 187 & 4,130 & 768 & 19,267 & 24,352 \\
\hline AFRC & 0 & 2,129 & 445 & 0 & 2,574 \\
\hline Discharged/Ex-SLA & 2,994 & 2,366 & 593 & 0 & 5,953 \\
\hline $\mathrm{CDF}$ & 2 & 8,800 & 524 & 28,051 & 37,377 \\
\hline $\begin{array}{l}\text { Others (including } \\
\text { paramilitary) }\end{array}$ & 0 & 1,473 & 298 & 463 & 2,234 \\
\hline Total & 3,183 & 18,898 & 2,628 & 47,781 & 72,490 \\
\hline
\end{tabular}

Source: NCDDR, August 2002 cited in Thusi and Meek (2003).

In terms of the level of involvement of children in the Sierra Leonean crisis which recorded involvement of thousands of combatants, it was revealed that a high percentage of children were experts in handling AK47 and other assault rifles than pistols, heavy machine guns and rocket propelled grenade launchers (Weiss, 2005). This contributed to the level of their brutality during the war.

It should be noted that the high intensity of the war in Sierra Leone greatly contributed to the greater number of ex-combatants disarmed and the volume of weapons collected and later destroyed.

The final stage, reintegration is premised on the fact that without a successful reintegration, the DDR programme will not be totally successful. About 56,700 former combatants were registered in the reintegration progarmme by December 2002, a year after the completion of disarmament and demobilisation phases. By January 2004, a total of 51,122 former combatants had received some sort of support: vocational training/ apprenticeship $(28,901)$, formal education $(12,182)$, resources to pursue agriculture $(9,231)$, job placement (444), and other (364) (United Nations, 2001). According to the UN report, former combatants in Sierra Leone that did not go through the reintegration process were given a one-time payment of $\$ 150$ and one implication is that payment is not adequate post-conflict initiative. 


\section{Lessons and challenges of Disarmament, Demobilisation, and Reintegration in Sierra Leone}

Lessons from the historical development of DDR in Sierra Leone are noteworthy. First, focusing on the issues that require conflict transformation rather than actors remains critical for sustainable peace, and this prevents the collapse of peace agreements and guarantees the success of conflict transformation. Secondly, multiplicity of actors reveals it was high intensity war. It is remarkable that lack of confidence in peace agreements motivates remobilisation which makes high intensity conflicts intractable, and this is why confidence building is necessary.

The third lesson is that most times, warlords and rebel groups see themselves as saviours of the people and are motivated by the theory of victory which is the victorious perception that makes them see the end of battle to their own advantage.

DDR programmes also come with challenges. According to United Nations Office of the Special Adviser on Africa (2005) there are several challenges that characterise the implementation of DDR programmes which hinder state-building in Africa. Some of these challenges are directly linked to delays in the design of DDR programmes while others are due to the absence of qualified and experienced DDR practitioners in peace negotiations and pressure from major partners to have peace agreements implemented in the shortest timeframe possible.

The DDR in Sierra Leone was top-down process (Asiedu \& Berghs, 2012) to the extent that it did not properly engage people at the communal level. The community-centric approach of reintegration would have been more effective in the country. From noncompliance with peace agreements to the restructuring of the programme and resurgence of armed conflict, but stability was restored towards the last phase of DDR in 2001 (Ginifer \& Solomon, 2008). Titles given to female soldiers such as "females associated with the war," "dependents," or "camp followers" as noted by Mackenzie (2009) portray the reluctance of reintegration agencies to identify females who participated in war as soldiers; despite about 12 percent of the RUF members being women (Knight, 2008), meaning they were actively involved in the war. The problems that were inherent in the DDR in Sierra Leone resulted from poor conditions in the demobilisation camps as well as ex-combatants not receiving their entitlements at the right time (Thusi \& Meek, 2003). This seems to be a common problem with many DDR programmes.

The problem of resource use characterised the demobilisation and rehabilitation phases of the DDR in Sierra Leone where limited space and food in camp had to be shared with dependants and ex-combatants. Managing such a problem was challenging as access to welfare materials became an issue. This was an error on the part of managers who implemented the programme (Kai-Kai, 2006). Some ex-combatants were reluctant to leave rehabilitation centres after discharge, and the problem of double identity manifested 
in the DDR package delivery as some people who were designated former combatants later claimed victim status and benefited again from the victims fund, while some others received nothing (Asiedu \& Berghs, 2012).

There was a notable problem of threat of incomplete weapons surrender and perception of remobilisation by some rebel members who were expected to participate in the DDR.

This is because partial surrendering of weapons by combatants poses grave danger to the success of DDR programme. The problem of insincerity played out in Sierra Leone where there was insincerity by one or both parties i.e. the RUF could not be trusted in sustaining the agreement especially from their record of launching attacks in Freetown in 2000 which also affected UNAMSIL peacekeepers (Smith, 2001). This lack of trust and readiness to be trusted threatened the process. According to Theidon (2007) DDR programmes will be increasingly forced to consider the ' $R$ ' that traditionally seems to be the weakest link in the chain; therefore, going beyond the measures that prioritise offering repentant belligerents some incentive for accepting ceasefire, in preparation for disarmament and demobilisation, which would surely create way for the truth, justice and reconciliation.

Post-DDR confidence building has centred on youth-focused peacebuilding which seeks to give the youth a sense of belonging through reorientation as well as the enlightenment of elders and other stakeholders on inclusion of youths in the area of community development and decision making, being more beneficial than a situation where elders list the dangers of youths questioning their authority (Tom, 2014). Such participatory development remains critical in discouraging the resurgence of arms proliferation and rebellious activities. Community awareness and development remain crucial to national stability.

Since the completion of DDR, post-conflict sensitisation by non-governmental organisations in form of radio jingles, cultural activities, community-level discussions, have dominated peace awareness campaigns that are aimed at sustaining the atmosphere of positive peace (Kilroy, 2014; Tom, 2014). Such channels are instrumental to conflict prevention, peacebuilding and community security provision. This should be supported by Paramount Chiefs through their timely response to various concerns of youths in the rural governance especially their involvement in handling social relations to complement the efforts of government promoting empowerment of young people. Traditional institutions especially the chiefdoms have a role to play in sustaining the peace, by emphasising on the benefits of peacefulness, inclusiveness and equal rights for all to enable the youth especially those who were children or not born during the war, to appreciate peace and eschew any act of conflict in communities. So far, the success of the DDR manifests in the non-militarisation of communities, as the security forces cooperate with people including youths in the society. 


\section{Conclusion}

The failure of governments to contain conflicts at latent phase explains why the problems escalate thereby making it difficult for conflict transformation that would be acceptable to the actors to take place. This is why history should be our guide in using past events to prevent contemporary problems. From the time the government of Sierra Leone lost control of the country, it was obvious its monopoly of violence had declined thereby creating the need for the involvement of more stakeholders from outside the country who were expected to broker peace and sustainable security. A recurring challenge facing most peace initiatives is that various governments seem to be more interested in the success of disarmament and demobilisation phases than complete reintegration of ex-fighters. The short period of rehabilitation does no help the situation as desired.

During the peacebuilding initiatives, the government was planning and initiating DDR, while the rebels were making their position hardened and focused on what they intended to gain, thereby making remobilisation a reality. The success of the statebuilding was as a result of the joint problem solving approach adopted by the National Committee for Disarmament, Demobilisation and Reintegration (NCDDR), Executive Secretariat, ECOMOG forces, the UN Observer Mission in Sierra Leone (UNAMSIL) and other stakeholders.

Sierra Leone's DDR process is regarded as rewarding with positive outcome, as elements of the Sierra Leone 'model' were replicated in neighbouring Liberia, in Burundi, and as well as Haiti. A total of 72,490 combatants were disarmed and 71,043 demobilised, and 63,545 former combatants participated in the reintegration segment, including 6,845 child soldiers (Ginifer \& Solomon, 2008; Kilroy, 2014). Participation rates in the DDR programme were high and peace has been maintained in Sierra Leone for over two decades since the end of the civil war.

Findings from this study show that poor ethical consideration could affect any peace agreement, thereby undermining a DDR programme. That is why stakeholders need to remain committed to avoid acts that encourage negative peace. Sustenance of good governance and improved social integration could be significant in addressing some of the challenges inherent in DDR programmes. The roles played by the security forces in the armed conflicts make it pertinent for security sector reforms to be one of the first priorities and remains strategic just like the DDR itself. The fact that in Sierra Leone, some members of the armed forces fought against the government and its interests, indicated that even after DDR there was need for continuous confidence building initiatives to avoid remobilisation for sustainable peace. This study argues that the remobilisation of combatants after peace agreements increased the intensity of the war which necessitated more external intervention to create enabling environment for state building and security sector reforms. Sustaining peace in Sierra Leone demands continuous 
empowerment of youths and their active involvement in informal peace education. Therefore, post-DDR peacebuilding should be more youth-focused and development oriented to prevent the resurgence of armed conflicts.

It is hoped that Sierra Leone would not experience such a devastating war in the future and this can only be guaranteed when continuous security guarantees and provision of basic human needs are prioritised to motivate ex-combatants to remain peaceful and shun any temptation remobilisation. It is recommended that while DDR programme is ongoing, stakeholders should stop addressing ex-fighters with their group name to prevent giving them psychological strength or influence.

To overcome challenges in DDR, much attention should not only be given to disarmament and demobilisation phases of DDR, rehabilitation/reintegration phase demands more coordinated actions to ensure proper implementation of reinsertion and successful reintegration of ex-combatants into their communities. The Chiefs in rural areas, local government and leaders at the national level should not take for granted the experiences acquired by ex-combatants in terms of handling weapons to avoid the temptation of remobilisation. This could be achieved by giving them recognition as partners in peacebuilding and a sense of belonging in the governance of their communities and the entire country.

\section{References}

1. Abatneh, S. A. (2006). Disarmament, demobilisation, rehabilitation and reintegration of Rwandan child soldiers. MA dissertation, Department of Sociology, University of South Africa.

2. Asiedu, V., \& Berghs, M. (2012). Limitations of individualistic peacebuilding in postwar Sierra Leone. African Conflict \& Peacebuilding Review, 2(1), 136-151.

3. Ball, N., \& de Goor, L. V. (2006). Disarmament, demobilization and reintegration: Mapping issues, dilemmas and guiding principles. The Hague: The Netherlands Institute of International Relations.

4. Boersch-Supan, J. (2012). The generational contract in flux: Intergenerational tensions in post-conflict Sierra Leone. The Journal of Modern African Studies, 5(1), 25-51.

5. Botes, J. (2003). Conflict transformation: A debate over semantics or a crucial shift in the theory and practice of peace and conflict studies? International Journal of Peace Studies, 8(2), 1-27.

6. Boutwell, J., \& Klare, M. T. (2000). A scourge of small arms. Scientific American, 6, 48-53.

7. Cuny, F. C. (1991). Dilemmas of military involvement in humanitarian relief. In L. Gordenker and T. A Weiss (eds.), Soldiers, peacekeepers and disasters (pp. 52-81). London: Basingstoke.

8. Dupuy, K., \& Binningsbø, H. M. (2008). Buying peace with diamonds? Power-sharing agreements in Sierra Leone. Centre for the Study of Civil War, PRIC, Policy Brief 7. Oslo: International Peace Research Institute. 
9. Edeko, S. E. (2011). The proliferation of small arms and light weapons in Africa: A case study of the Niger Delta in Nigeria. Sacha Journal of Environmental Studies, 1(2), 55-80.

10. Edmonds, M., Mills, G., \& McNameee, T. (2009). Disarmament, demobilisation and reintegration and local ownership in the Great Lakes: The experience of Rwanda, Burundi, and the Democratic Republic of Congo. African Security, 2(1), 29-58.

11. Egeland, K. (2019). Oslo's "new track": Norwegian nuclear disarmament diplomacy, 2005-2013. Journal for Peace and Nuclear Disarmament, 2(2), 468-490.

12. Faleti, S. A. (2005). Termination of protracted social conflicts in Africa. In I. O. Albert (ed.), Perspectives on peace and conflict in Africa (pp. 370-390). Ibadan: John Archers Publishers.

13. Francis, D. J. (2000). Torturous path to peace: The Lome accord and postwar peacebuilding in Sierra Leone. Security Dialogue, 31(3), 357-373.

14. Galtung, J. (1996). Peace by peaceful means: Peace and Conflict, Development and Civilization. London: Sage.

15. Gberie, L. (2000). First stages on the road to peace: the Abidjan Process (1995-1996). Conciliation Resources. Retrieved from https://www.c-r.org/accord/sierra-leone/firststages-road-peace-abidjan-process-1995-96.

16. Gbla, 0. (2003). Conflict and postwar trauma among child soldiers in Liberia and Sierra Leone. In A. Sesay (ed.), Civil Wars, child soldiers and post conflict peace building in West Africa (pp. 167-194). Ibadan: College Press and Publishers Ltd.

17. Ginifer, J., \& Solomon, C. (2008). Disarmament, demobilisation and reintegration in Sierra Leone. DDR and human security: Post-conflict security-building in the interests of the poor. Bradford: Centre for International Cooperation and Security, University of Bradford.

18. Glen, E. S. (1981). Man and mankind: Conflict and communication between cultures. Norwood: Ablex.

19. Glen, E. S., Whitmeyer, D., \& Stevenson, K. A. (1977). Cultural styles of persuasion. International Journal of Intercultural Relations, 1(3), 52-66.

20. Griffiths, A., \& Barnes, C. (2008). Incentives and Sanctions in Peace Processes. GSDRC. Retrieved from https://gsdrc.org/document-library/powers-of-persuasion-incentiv es-sanctions-and-conditionality-in-peacemaking/.

21. Hanson, S. (2007). Disarmament, demobilisation and reintegration (DDR) in Africa. Backgrounder. New York: Council on Foreign Relations.

22. Hayner, P. (2007). Negotiating peace in Sierra Leone: Confronting the justice challenge. Geneva: Henry Dunant Centre for Humanitarian Dialogue.

23. Humphreys, M., \& Weinstein, J. M. (2007). Demobilization and reintegration. Journal of Conflict Resolution, 51(4), 531-567.

24. Humphreys, M., \& Weinstein, M. J. (2005). Disentangling the determinants of successful demobilization and reintegration. Paper presented at the annual meeting of the American Political Science Association, Washington, DC. 
25. Joshi, M., \& Quinn, J. M. (2012). Disarmament and demobilisation in comparative perspective: patterns and policy recommendations, Report 21. Oslo: The Norwegian Peaebuilding Resource Centre.

26. Kai-Kai, F. (2006). Disarmament, demobilisation and reintegration in post-war Sierra Leone. In A. Ayissi and R. E. Poulton (eds.), Bound to Cooperate: Conflict Peace and People in Sierra Leone (pp. 115-130). Geneva: United Nations Institute for Disarmament Research.

27. Kandeh, J. (2004). Coups from below: Armed Subalterns and State Power in West Africa. New York: Palgrave Macmillan.

28. Keili, F. L. (2008). Small Arms and Light Weapons Transfer in West Africa: A stock-taking. Disarmament Forum 4. Geneve: United Nations Institute for Disarmament Research.

29. Kilroy, W. (2014). Does a more participatory approach to reintegrating excombatants lead to better outcomes? Evidence from Sierra Leone and Liberia. Conflict, Security \& Development, 14(3), 275-308.

30. Knight, A. W. (2010). Linking DDR and SSR in post conflict peace-building in Africa: An overview. African Journal of Political Science and International Relations, 4(1), 29-54.

31. Kozan, M. K. (1997). Culture and conflict management: A theoretical framework. International Journal of Conflict Management, 8(4), 338-360.

32. Kozan, M. K. (2002). Subcultures and Conflict Management Style. MIR: Management International Review, 42(1), 89-105.

33. Knight, A. W. (2008). Disarmament, demobilization, and reintegration and post-conflict peacebuilding in Africa: An overview. African Security, 1(1), 24-52.

34. Lamback, D. (2007). Oligopolies of Violence in Post-Conflict Societies. Hamburg: GIGA Working Papers.

35. Laurence, J. E., \& Shie, R. T. (2003). Disarming for Peace in Aceh: Lessons Learned. Monterey: Monterey Institute of International Peace Studies.

36. Lederach, J. P. (1998). Beyond violence: Building sustainable peace. In E. Weiner (ed.), The handbook of interethnic coexistence (pp. 236-245). New York: Abraham Fund Publication.

37. Mackenzie, M. (2009). Securitization and desecuritization: Female soldiers and the reconstruction of women in post-conflict Sierra Leone. Security Studies, 18(2), 241-261.

38. Montague, D. (2002). The business of war and the prospects for peace in Sierra Leone. The Brown Journal of World Affairs, 9(1), 229-237.

39. Muggah, R. (2010). Innovations in disarmament, demobilization and reintegration policy and research: Reflections on the last decade. NUPI Working Paper 774. Oslo: Norwegian Institute of International Affairs.

40. Muggah, R. (2005). Managing post-conflict zones: DDR and weapons reduction. Small Arms Survey, 267-300.

41. Muggah, R., Maughan, P., \& Bugnion, C. (2003). The Long Shadow of War: Prospects for Disarmament, Demobilisation and Reintegration in the Republic of Congo. A Joint Evaluation for the European Commission, UNDP and MDRP Secretariat. 
42. Nolasco, L. K., \& Munene, M. (2012). Armed Pastoralists in North Rift Valley - a shift towards reintegration, demobilisation and disarmament. Horn of Africa Bulletin, 5-9.

43. Nwoko, K. C. (2011). A Bleak future, a wasted generation: Child Soldier in Africa, Issues of concern. Journal of Sustainable Development in Africa, 13(4), 1-17.

44. Obi, C. I. (2009). Economic Community of West African States on the Ground: Comparing Peacekeeping in Liberia, Sierra Leone, Guinea Bissau, and Côte D’Ivoire. African Security, 2(2-3), 119-135.

45. Ploughshares, (2002). Armed Conflicts Report: Sierra Leone. Retrieved from www. ploughshares.ca/libraries/ACRText/ACRSierraLeone.html.

46. Rakate, K. P. (2008). Is the Sierra Leonean amnesty law compatible with International Law? Sierra Herald, 6(8).

47. Raleigh, C., \& Dowd, C. (2012). Mapping conflict across Liberia and Sierra Leone. Accord, Issue 23.

48. Smith, D. (2001). Trends and causes of armed conflict. Berlin: Berghof Research Center for Constructive Conflict Management.

49. Theidon, K. (2007). Transitional subjects: The disarmament, demobilization and reintegration of former Combatants in Colombia. The International Journal of Transitional Justice, 1, 66-90.

50. Thusi, T., \& Meek, S. (2003). Disarmament, and demobilization in Sierra Leone. In M. Malan, S. Meek, T. Thusi, J. Ginifer and P. Coker (eds.), Building the road to recovery (pp. 23-38). ISS Monograph 80. Pretoria: Institute for Security Studies.

51. Tom, P. (2014). Youth-traditional authorities' relations in post-war Sierra Leone. Children's Geographies, 12(3), 327-338.

52. Ukeje, C. (2003). Sierra Leone: The Long Decent into Civil War. In A. Sesay (ed.), Civil Wars, Child Soldiers and Post Conflict Peace Building in West Africa (pp. 113-131). Ibadan: College Press and Publishers.

53. UNAMSIL, (2003). DDR Lessons Learned in Sierra Leone - DDR Coordination Sectio, UNAMSIL, August, p. 412 para. 51.

54. United Nations. (2000). Report of the Secretary General: The role of United Nations peacekeeping in disarmament, demobilization and reintegration. S/2000/101 of 11 February.

55. Varisco, A. E. (2009). A Study on the inter-relation between armed conflict and natural resources and its implications for conflict resolution and Peacebuilding. Journal of Peace, Conflict and Development, 14, 38-58.

56. Väyrynen, R. (1999). From Conflict Resolution to Conflict Transformation: A Critical Review. In H.-W Jeong (ed.), The New Agenda for Peace Research (pp. 135-160). Sydney: Ashgate.

57. Weiss, T. (2005). Perpetrating power: Small arms in post-conflict Sierra Leona and Liberia. ISS monograph series no. 116. Pretoria: Institute for Security Studies. 